\title{
A Research on the Burnout and the Teaching Profession Attitudes of Teacher Candidates
}

\author{
Ayşegül Kadı ${ }^{1}$, Osman Ferda Beytekin ${ }^{1}$, Hasan $\operatorname{Arslan}^{2}$ \\ ${ }^{1}$ Ege University, Faculty of Education, Turkey \\ ${ }^{2}$ Onsekiz Mart University, Faculty of Education, Turkey \\ Correspondence: Ayşegül Kadı, Ege University, Faculty of Education, Turkey
}

Received: January 8, 2015 Accepted: January 27, 2015 Online Published: February 12, 2015

doi:10.11114/jets.v3i2.677 URL: http://dx.doi.org/10.11114/jets.v3i2.677

\begin{abstract}
Purpose of this study is to examine burnout and teaching profession attitudes of teacher candidates. Research was conducted with 287 teacher candidates. By the findings; burnout and teaching profession attitudes of teacher candidates don't differ according to their gender. Burnout of teacher candidates differs according to their graduation status but teaching profession attitudes of teacher candidates don't differ according to their graduation status. Emotional exhaustion points of teacher candidates differ according to their field of study. Teacher candidates in art teaching have the highest emotional exhaustion mean ranks and teacher candidates in nursing have the lowest emotional exhaustion mean ranks. Lack of personal accomplishment points of teacher candidates differ according to their field of study. Teacher candidates in American culture and literature have the highest lack of personal accomplishment mean ranks and teacher candidates in Turkish teaching have the lowest lack of personal accomplishment mean ranks. Depersonalization points of teacher candidates differ according to their field of study. Teacher candidates in journalism have the highest lack of personal accomplishment mean ranks and teacher candidates in German language and literature have the lowest lack of personal accomplishment mean ranks. Teaching profession attitude points of teacher candidates differ according to their field of study. Teacher candidates in geography have the highest teaching profession attitude mean ranks and teacher candidates in journalism have the lowest teaching profession attitude mean ranks. Additionally, burnout of teacher candidates explains 9\% of the total variance of their teaching profession attitude. Examining the results of the t-test, competence and depersonalization are seen to be the significant predictors of teacher candidates' teaching profession attitude.
\end{abstract}

Keywords: Burn out, teaching profession, teacher candidates

\section{Introduction}

A teacher is an important element of an education system because the impact of the teachers on the students and education programs is known much higher than other elements. If teachers want to be successful in this profession, they have to accept the profession unconditionally, and do it with love and passion (Çetin, 2006).

The profession they choose shape individuals' lives (Bozdoğan, Aydın, \& Yıldırım, 2007) and a person can develop intellectual and emotional approaches regarding their profession so these approaches are reflected in their behaviors (Korkmaz, 2009). Emotional tendency of an individual in favor of or against any circumstances, events, objects, places or ideas can mean attitudes (Papanastasiou, 2002; Tavşanc1l, 2006; Temizkan, 2008). An attitude which is developed towards a profession is the most important indicator of success in that profession (Çakır, 2005; Durmuşoğlu, Yanık, \& Akkoyunlu, 2009). If an individual does not like his or her profession, he or she may not practice it successfully (Terzi \& Tezci, 2007). Teaching requires affective competences besides knowledge and skills. Developing a positive attitude towards teaching profession affects all the factors related to the teaching (Can, 2010). Therefore, determining the attitudes of teacher candidates towards their prospective profession and making their attitudes positive is important (Semerci \& Semerci, 2004). There are many studies in the literature concerning attitudes towards teaching profession (Aksoy, 2010; Çapri \& Çelikkaleli, 2008; Çetinkaya, 2007; Kaşkaya, Ünlü, Akar, Sağırlı, \& Özturan, 2011; Özbek, Kahyaoğlu, \& Özgen, 2007; Kahyaoğlu, Tan \& Kaya, 2013; Kartal \& Afacan, 2012; Doğan \& Çoban, 2009). 
Burnout is known as one of the most important problems of modern times. Freudenberger (1974) defines burnout as ineffectiveness, wearing out, lack of energy and power, and an exhaustion of the inner resources of an individual due to unsatisfied needs. Maslach Burnout Model, is commonly accepted and explains burnout in three ways (Maslach \& Marek, 1993). According to this model, burnout has three dimensions as emotional exhaustion, depersonalization, and lack of personal accomplishment (Maslach, Schaufeli \& Leiter, 2001). The measurement device based on this model (Maslach Burnout Inventory) is primarily administered to professionals experiencing face-to-face relationship in areas such as health, education, and social work. There are many studies in the literature concerning attitudes towards burnout (Sarıgöz \& Çermik, 2013; Ören \& Türkoğlu, 2006; Kutsal \& Bilge, 2012; Aypay, 2011; Maraşl1, 2005; Zhang, Gan \& Cham, 2005).

Conducting researches about teaching profession and burnout and generating education policies according to the results is important. However, only a limited number of researches have examined the relationship between burnout of teacher candidates and their attitudes towards the teaching profession. For this reason, conducting this study is expected to fill these blanks in literature and provide important benefits to researchers and implementers. The problems depending on this purpose were determined as below:

- Do burnout and teaching profession attitudes of teacher candidates differ according to their gender?

- Do burnout and teaching profession attitudes of teacher candidates differ according to their graduation status?

- Do burnout and teaching profession attitudes of teacher candidates differ according to their field of study?

- Does burnout of teacher candidates predict their teaching profession attitudes?

\section{Methodology}

\subsection{Research Model}

Research design is determined as survey model to examine the difference between burnout and teaching profession attitudes of teacher candidates according to independent variables. Survey model is used to identify people's attitudes, beliefs, values, habits, thoughts (Mcmillan \& Schumacher, 2001). Besides, the study's design is correlational because predicting statistics is used to examine whether burnout of teacher candidates predicts their teaching profession attitudes. Correlational studies aim to reveal correlational relationships between variables using correlational statistics (Balc1, 2011).

\subsection{Population and Sample}

The accessible population of the study consists of teacher candidates at Ege University, Faculty of Education in the 2014-2015 academic year. The sample of the study is determined by convenience sampling method and the research was conducted with 287teacher candidates. This method can be applied when sample units are selected from easily accessible due to the existing limitations of the money, time and workforce (Büyüköztürk, Kılıç Çakmak, Akgün, Karadeniz \& Demirel, 2011).

The frequencies are given according to the participants' gender, classroom level and field of the study (Table 1).

Table 1. Demographic information of teacher candidates participating in research

\begin{tabular}{llll}
\hline Variable & Groups & $\mathrm{n}$ & $\%$ \\
\hline Gender & Female & 205 & 71,4 \\
& Male & 82 & 28,6 \\
Graduation status & Sum & 287 & 100,0 \\
& Under graduate & 238 & 82,9 \\
& University student & 49 & 17,1 \\
& Total & 287 & 100,0 \\
& Geography & 32 & 11,1 \\
& Physics & 5,2 & 10,8 \\
& Mathematics & 15 & 9,1 \\
& Biology & 31 & 4,9 \\
& History of art & 26 & 2,1 \\
& American culture and literature & 14 & 13,6 \\
& English language and literature & 6 & 1,7 \\
& German language and literature & 39 &, 3 \\
& Journalism & 5 & 10,8 \\
& Turkish language and literature & 1 & 2,8 \\
Art teaching & 31 & 10,5 \\
& Turkish teaching & 8 & 15,0 \\
& Music & 30 & 2,1 \\
& Nursing & 43 & 100,0 \\
\hline
\end{tabular}




\subsection{Instruments}

As instruments, Maslach Burnout Inventory - Student Scale adapted by Çapri, Gündüz \& Gökçakan (2011) and Attitude Scale towards the Profession of Teaching developed by Üstüner (2006) are used to gather the data of the research.

\subsubsection{Attitude Scale towards the Profession of Teaching}

The exploratory factor analysis was applied to examine the factor structure of the Attitude Scale towards the Profession of Teaching developed by Üstüner (2006). It was seen that the tool had the structure of one dimension consisting of 34 items. Among them 24 items represent positive attitudes, while 10 of them (2nd, 5th, 6th, 7th, 8th, 15th, 20th, 21st, 30 th, 32nd) represent negative attitudes. In the analysis, the overall Cronbach alpha reliability coefficient of Attitude Scale towards the Profession of Teaching was calculated and the coefficient was found 0.93 . Responses given items are rated as $\ll 5=$ strongly agree, $4=$ Mostly agree, $3=$ moderately agree, $2=$ partly agree, $1=$ strongly disagree.

\subsubsection{Maslach Burnout Inventory-Student Scale}

The exploratory factor analysis was applied to examine the factor structure of the Maslach Burnout Inventory - Student Scale adapted by Çapri, Gündüz \& Gökçakan (2011). It was seen that the tool had a structure of three dimensions consisting of 13 items. The scale contains three factors as emotional exhaustion, depersonalization, and lack of personal accomplishment. Responses given to items are rated as «1= never», «2=sometimes», «3= usually», «4=often», «5= always». The coefficient was .89 for the overall scale. Cronbach's Alpha coefficient for internal consistency has been found for 3 factors $.76, .82$ and .61 .

\subsection{Analyses}

SPSS 17.00 program is used in the analysis of the data. Independent Samples T Test and Kruskal Wallis Test are used to examine the difference between the burnout and teaching profession attitudes of teacher candidates according to independent variables. Multiple Linear Regression is used to examine whether burnout of teacher candidates predicts their teaching profession attitude and.05 level of significance was taken for the interpretation of the results.

\section{Results}

Data obtained from Maslach Burnout Inventory - Student Scale and Attitude Scale towards the Profession of Teaching Scale were analyzed. The findings are as follows:

Table 2. Independent Samples T Test Results of Burnout and Teaching Profession Attitude of Teacher Candidates According To Gender

\begin{tabular}{|c|c|c|c|c|c|c|}
\hline Points & Gender & $\mathrm{N}$ & $\mathrm{M}$ & S.s. & $\mathrm{T}$ & $\mathrm{P}$ \\
\hline \multirow[t]{2}{*}{ Emotional exhaustion } & Male & 205 & 12,82 & 4,34 & ,23 & ,82 \\
\hline & Female & 82 & 12,70 & 4,31 & & \\
\hline \multirow[t]{2}{*}{ Lack of personal accomplishment } & Male & 205 & 13,36 & 2,81 & 1,17 & ,24 \\
\hline & Female & 82 & 12,93 & 2,90 & & \\
\hline \multirow[t]{2}{*}{ Depersonalization } & Male & 205 & 8,45 & 3,55 &,- 26 &, 80 \\
\hline & Female & 82 & 8,57 & 3,67 & & \\
\hline \multirow[t]{2}{*}{ Teaching profession attitude } & Male & 205 & 139,28 & 20,09 & 1,11 &, 27 \\
\hline & Female & 82 & 136,35 & 20,60 & & \\
\hline
\end{tabular}

Burnout and teaching profession attitudes of teacher candidates don't differ according to their gender ( $\mathrm{p}>$.05).Accordingly, it can be said that gender doesn't have a significant effect on burnout and teaching profession attitudes of teacher candidates.

Table 3. Independent Samples T Test Results of Burnout and Teaching Profession Attitude of Teacher Candidates According To Graduation Status

\begin{tabular}{lllllll}
\hline Points & Graduation & $\mathrm{N}$ & $\mathrm{M}$ & $\mathrm{S} . \mathrm{s}$. & $\mathrm{T}$ & $\mathrm{P}$ \\
\hline Emotional exhaustion & Undergraduate & 238 & 12,48 & 4,18 & $, 2,69$ &, 01 \\
\multirow{2}{*}{$\begin{array}{l}\text { Lack of } \\
\text { accomplishment }\end{array}$} & University student & 49 & 14,29 & 4,75 & & \\
Depersonalization & Undergraduate & 238 & 13,40 & 2,83 & 2,15 &, 03 \\
\multirow{2}{*}{ Teaching profession attitude } & University student & 49 & 12,45 & 2,79 & & \\
& Undergraduate & 238 & 8,14 & 3,28 & $-3,02$ &, 00 \\
& University student & 49 & 10,16 & 4,45 & & \multirow{2}{*}{, 37} \\
& Undergraduate & 238 & 138,93 & 19,99 &, 90 & \\
\hline
\end{tabular}

Burnout of teacher candidates differs according to graduation status but teaching profession attitudes of teacher candidates don't differ according to graduation status. Accordingly, it can be said that graduation status doesn't have a significant effect on teaching profession attitude of teacher candidates but graduation status has a significant effect on burnout of teacher candidates. University students have higher emotional exhaustion and depersonalization points than undergraduates. Undergraduates have higher lack of personal accomplishment points than university students. 
Table 4. Kruskal Wallis Test Results of Emotional Exhaustion of Teacher Candidates According To Field of Study

\begin{tabular}{|c|c|c|c|c|c|}
\hline Point & Field & $\mathrm{N}$ & Mean Rank & $\mathrm{X}^{-}$ & $\mathrm{P}$ \\
\hline Emotional & Geography & 32 & 144,58 & 26,66 & 01 \\
\hline \multirow[t]{13}{*}{ exhaustion } & Physics & 15 & 136,27 & & \\
\hline & Mathematics & 31 & 151,13 & & \\
\hline & Biology & 26 & 174,42 & & \\
\hline & History of art & 14 & 111,00 & & \\
\hline & American culture and literature & 6 & 112,42 & & \\
\hline & English language and literature & 39 & 162,01 & & \\
\hline & German language and literature & 5 & 138,70 & & \\
\hline & Journalism & 1 & 171,50 & & \\
\hline & Turkish language and literature & 31 & 125,10 & & \\
\hline & Art teaching & 8 & 193,25 & & \\
\hline & Turkish teaching & 30 & 175,65 & & \\
\hline & Music & 43 & 108,86 & & \\
\hline & Nursing & 6 & 108,50 & & \\
\hline
\end{tabular}

Emotional exhaustion points of teacher candidates differ according to field of study(p<.05). Teacher candidates in art teaching have the highest emotional exhaustion mean ranks and teacher candidates in nursing have the lowest emotional exhaustion mean ranks.

Table 5. Kruskal Wallis Test Results of Lack of Personal Accomplishment of Teacher Candidates According To Field of Study

\begin{tabular}{|c|c|c|c|c|c|}
\hline Points & Field & $\mathrm{N}$ & Mean Rank & $\mathrm{X}$ & $\mathrm{P}$ \\
\hline $\begin{array}{l}\text { Lack of personal } \\
\text { accomplishment }\end{array}$ & $\begin{array}{l}\text { Geography } \\
\text { Physics } \\
\text { Mathematics } \\
\text { Biology } \\
\text { History of art } \\
\text { American culture and literature } \\
\text { English language and literature } \\
\text { German language and literature } \\
\text { Journalism } \\
\text { Turkish language and literature } \\
\text { Art teaching } \\
\text { Turkish teaching } \\
\text { Music } \\
\text { Nursing }\end{array}$ & $\begin{array}{l}32 \\
15 \\
31 \\
26 \\
14 \\
6 \\
39 \\
5 \\
1 \\
31 \\
8 \\
30 \\
43 \\
6\end{array}$ & $\begin{array}{l}124,42 \\
178,33 \\
144,50 \\
142,94 \\
112,79 \\
226,33 \\
138,74 \\
165,70 \\
135,00 \\
169,53 \\
151,56 \\
111,95 \\
141,73 \\
207,17\end{array}$ & 24,02 & ,03 \\
\hline
\end{tabular}

Lack of personal accomplishment points of teacher candidates differ according to field of study $(\mathrm{p}<.05)$. Teacher candidates in American culture and literature have the highest lack of personal accomplishment mean ranks and teacher candidates in Turkish teaching have the lowest lack of personal accomplishment mean ranks.

Table 6. Kruskal Wallis Test Results of Depersonalization of Teacher Candidates According To Field of Study

\begin{tabular}{|c|c|c|c|c|c|}
\hline Points & Field & $\mathrm{N}$ & Mean Rank & $\mathrm{X}$ & $\mathrm{P}$ \\
\hline Depersonalization & $\begin{array}{l}\text { Geography } \\
\text { Physics } \\
\text { Mathematics } \\
\text { Biology } \\
\text { History of art } \\
\text { American culture and literature } \\
\text { English language and literature } \\
\text { German language and literature } \\
\text { Journalism } \\
\text { Turkish language and literature } \\
\text { Art teaching } \\
\text { Turkish teaching } \\
\text { Music } \\
\text { Nursing }\end{array}$ & $\begin{array}{l}32 \\
15 \\
31 \\
26 \\
14 \\
6 \\
39 \\
5 \\
1 \\
31 \\
8 \\
30 \\
43 \\
6\end{array}$ & $\begin{array}{l}143,33 \\
150,43 \\
146,65 \\
186,60 \\
107,25 \\
108,83 \\
147,21 \\
82,10 \\
251,00 \\
140,27 \\
194,06 \\
191,05 \\
98,99 \\
106,92\end{array}$ & 42,29 & ,00 \\
\hline
\end{tabular}

Depersonalization points of teacher candidates differ according to field of study ( $p<.05)$. Teacher candidates in journalism have the highest lack of personal accomplishment mean ranks and teacher candidates in German language and literature have the lowest lack of personal accomplishment mean ranks. 
Table 7. Kruskal Wallis Test Results of Teaching Profession Attitude of Teacher Candidates Changing According To Field of Study

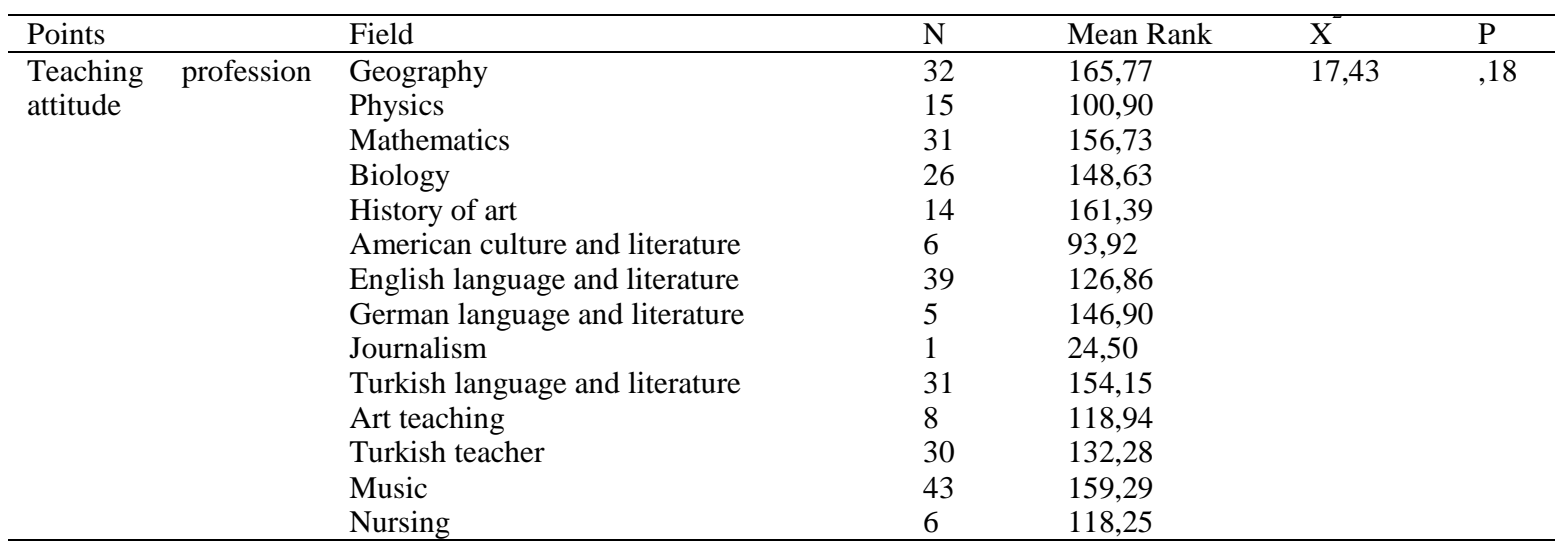

Teaching profession attitude points of teacher candidates differ according to field of study ( $<<.05)$. Teacher candidates in geography have the highest teaching profession attitude mean ranks and teacher candidates in journalism have the lowest teaching profession attitude mean ranks.

Table 8. Multiple Linear Regression Analysis Results

\begin{tabular}{llllll}
\hline Variables & $\mathrm{B}$ & Standard error & $\beta$ & $\mathrm{t}$ & $\mathrm{p}$ \\
\hline Constant & 128,470 & 7,121 & & 18,040 &, 000 \\
Emotional exhaustion &, 542 &, 352 &, 116 & 1,541 &, 124 \\
Lack of personal accomplishment & 1,270 &, 412 &, 178 & 3,083 &, 002 \\
depersonalization & $-1,622$ &, 428 &,- 287 & $-3,791$ &, 000 \\
\hline $\mathrm{R}=.31, \mathrm{R}=.10$, Adjusted R $=.09 \mathrm{~F}(3-283)=10,18 \mathrm{p}=.00$ & & & & \\
\hline
\end{tabular}

Burnout of teacher candidates explains $9 \%$ of the total variance of teaching profession attitude. Examining the results of $\mathrm{t}$-test, competence and depersonalization are seen to be the significant predictors of teaching profession attitude.

\section{Discussion and Conclusion}

In this research, the results revealed that burnout and teaching profession attitudes of teacher candidates don't differ according to their gender. Accordingly, it can be said that gender doesn't have a significant effect on burnout and teaching profession attitudes of teacher candidates. On the contrary, Üstüner, Demirtaş \& Cömert (2009) found that; a significant difference was observed between the attitudes of prospective teachers about profession of teaching according to their gender. Similarly, the results of Gündüz, Çapri \& Gökçakan (2012) indicate that burnout scores of students differ according to their gender. In addition, Baş (2012) found that students' burnout perceptions statistically differ according to gender.

Furthermore, the results of this study indicated that burnout of teacher candidates differ according to their graduation status but teaching profession attitudes of teacher candidates don't differ according to their graduation status. Accordingly, it can be said that graduation status doesn't have a significant effect on teaching profession attitude of teacher candidates but graduation status has a significant effect on burnout of teacher candidates. Besides, the results revealed that university students have higher emotional exhaustion and depersonalization points than undergraduates and undergraduates have higher lack of personal accomplishment points than university students. Similarly, Kaya \& Arı̈z (2014) found that there was a statistical significant difference between the emotional burnout according to class levels of the students. Furthermore, the results of Gündüz, Çapri \& Gökçakan (2012) indicated that burnout scores of students differed according to their grade. Correspondingly, Baş (2012) found that students' burnout perceptions statistically differ according to their classroom level.

The results of this study revealed that emotional exhaustion points of teacher candidates differed according to the field of study. Teacher candidates in art teaching have the highest emotional exhaustion mean ranks and teacher candidates in nursing have the lowest emotional exhaustion mean ranks. Lack of personal accomplishment points of teacher candidates differ according to field of their study. Teacher candidates in American culture and literature have the highest lack of personal accomplishment mean ranks and teacher candidates in Turkish teaching have the lowest lack of personal accomplishment mean ranks. Depersonalization points of teacher candidates differ according to field of study. Teacher candidates in journalism have the highest lack of personal accomplishment mean ranks and teacher candidates in German language and literature have the lowest lack of personal accomplishment mean ranks. Teaching profession attitude points of teacher candidates differ according to field of study. Teacher candidates in geography have the highest teaching profession attitude mean ranks and teacher candidates in journalism have the lowest teaching profession 
attitude mean ranks. The results of Ören \& Türkoğlu (2006) similarly indicate that burnout scores of students differ according to field of study. Üstüner, Demirtaş \& Cömert (2009) also found that there was a significant difference between the attitudes of prospective teachers about profession of teaching according to field of study.

Additionally, burnout of teacher candidates explains $9 \%$ of the total variance of teaching profession attitudes. Examining the results of t-test, competence and depersonalization are seen to be significant predictors of teaching profession attitude. Appropriately, Bektaş \& Nalçac1 (2012) found a significant positive relationship between the variables of the personal values of the teacher candidates and their attitudes towards teaching profession. Consequently, Çapulcuoğlu \& Gündüz (2013) found that academic self-efficacy was the most effective in predicting the burnout, depersonalization and coping with stress is the second variable predicting high school students' burnout, and that there was a negative relationship between using positive coping methods and burnout, and a positive relationship between using negative coping methods and burnout. In respect to Ayık \& Ataş (2013) there was a significant relationship between pre-service teachers' teaching motivation and attitudes towards the teaching profession.

The research reveals that the burnout and teaching profession attitudes of teacher candidates increases the level of quality of teacher education. Therefore, analyzing burnout and teaching profession attitudes of teacher candidates is expected to be used as a leverage to manage the faculty effectively and provide important benefits to researchers and implementers. According to the findings, burnout of teacher candidates differs according to their graduation status and field and so the reasons of these findings can be investigated. Finally, the research results show that burnout of teacher candidates explains $9 \%$ of the total variance of teaching profession attitude and so teaching profession attitudes can be affected by other variables and these variables may be investigated.

\section{References}

Aksoy, M. E. (2010). Attitudes toward teaching profession of teacher candidates. Gaziosmanpaşa University Journal of Social Sciences Researches, 5(2), 197-212.

Ayık, A., \& Ataş, Ö. (2013). The relationship between pre-service teachers' attitudes towards the teaching profession and their motivation to teach. Journal of Educational Sciences Research, 4 (1), 25-43.

http://dx.doi.org/10.12973/jesr.2014.41.2

Aypay, A. (2011). Elementary school student burnout scale for grades 6-8: A study of validity and reliability. Educational Sciences: Theory \& Practice, 11(2), 511-527.

Balc1, A. (2011). Social Science Research Methods, Techniques and Principles. Ankara: Pegem Akademi.

Baş, G. (2012). Burnout in elementary students: An evaluation with respect to some variables. Journal Of European Education, 2(2), 31-46.

Bektaş, F., \& Nalçacı, A. (2012). The Relationship between Personal Values and Attitude towards Teaching Profession. Educational Sciences: Theory \& Practice, 12 (2), 1244-1248.

Bozdoğan, A. E., Aydın, D., \& Yıldırım, K. (2007). Attitudes of teacher candidates towards teaching profession. Kırşehir Ahi University Kırşehir Faculty of Education Journal, 8 (2), 83-97.

Büyüköztürk, Ş., Kılıç, E., Akgün,Ö., Karadeniz, Ş., \& Demirel, F. (2011). Scientific Research Methods. Ankara: Pegem Akademi.

Can, Ş. (2010). Attitudes of the students who attend the non-thesis graduated education program towards the teaching profession. Muğla University Institute of Social Sciences Journal, 24, 13-28.

Çakır, Ö. (2005). Anadolu university faculty of education English teaching degree program and attitudes about profession and perceptions about professional competence of English teaching degree program students. Inönü University Faculty of Education Journal, 9 (6), 27-42.

Çapri, B., Gündüz, B., \& Gökçakan, Z. (2011). Maslach Tükenmişlik Envanteri-Öğrenci Formu (MTE-ÖF)'nun Türkçe’ye Uyarlaması: Geçerlik ve Güvenirlik Çalışması, Çukurova Üniversitesi Eğitim Fakültesi Dergisi. 40 (1), 134-147.

Çapri, B., \& Çelikkaleli, Ö. (2008). Investigation of pre-service teachers' attitudes towards teaching and professional self-efficacy beliefs according to their gender, programs, and faculties. Inönü University Faculty of Education Journal, 9 (15), 33-53.

Çetinkaya, R. (2007). Efficacy perceptions and attitudes towards the teaching profession of Turkish teacher candidates. Unpublished master's thesis, Selçuk University, Konya.

Çapulcuoğlu, U., \& Gündüz, B. (2013). Coping with stress, test anxiety, academic self-efficacy and parental attitudes in predicting student burnout. Journal of Educational Sciences Research, 3 (1), 201-218. 
http://dx.doi.org/10.12973/jesr.2013.3111a

Çetin, Ş. (2006). Establishment of the profession of teaching attitude scale (The study for validity and confidence). Gazi University Faculty of Industrial Arts Education Journal, 18, 28-37.

Doğan, T., \& Çoban, A. (2009). The investigation of the relations between students' attitude toward teaching profession and anxiety level in faculty of education. Education and Science, 34(153), 157-167.

Durmuşoğlu, M. C., Yanık, C., \& Akkoyunlu, B. (2009). Turkish and Azerbaijani prospective teachers' attitudes to their profession. H.U. Journal of Education, 36, 76-86.

Freudenberger, H. J. (1974). Staff burnout. Journal of Social Issue, 30, 159-165. http://dx.doi.org/10.1111/j.1540-4560.1974.tb00706.x

Kahyaoğlu, M., Tan, M., \& Kaya, M. (2013). Pre-service teachers' learning styles and attitude towards teaching profession. Mustafa Kemal University Journal of Social Sciences Institute, 10(21), 225-236.

Kaşkaya, A., Ünlü, İ., Akar, M., Sağırlı, S. \& Özturan M. (2011). The effect of school and teacher themed movies on pre-service teachers' professional attitudes and perceived self-efficacy. Educational Sciences: Theory \& Practice, $11,1765-1783$.

Kartal, T., \& Afacan, Ö. (2012). Examining attitudes of prospective teachers who took pedagogical formation Kaya, D. \& Arı̈z, A. (2014). Burnout level of midwife and nurse students and triggering factors. Selcuk University Journal of Institute of Social Sciences, 31, 89-99.

Kutsal, D., \& Bilge, F. (2012). A study on the burnout and social support levels of high school students. Education and Science, 37(164), 283-297.

Maraşl1, M. (2005). Burnout levels of high school teachers according to some properties and learned strength level. Turkish Journal of Occupational Health and Safety, 23, 27-34.

Maslach, C., Schaufeli, W. B., \& Leiter, M. P. (2001). Job burnout. Annual Review of Psychology, 52, 397-442. http://dx.doi.org/10.1146/annurev.psych.52.1.397

Maslach, C., \& Marek, T. (1993). Professional burnout: recent developments in theory and research. Washington DC: Taylor \& Francis.

Mcmillan, J. H., \& Schumacher, S. (2001). Research in education. A conceptual introduction (5th ed.). New York: Addison Wesley Longman.

Ören, N., \& Türkoğlu, H. (2006). The exhaustion levels of teacher candidate. Muğla University Social Sciences Institute Journal, 16.

Özbek, R., Kahyaoğlu M., \& Özgen, N. (2007). Evaluation of candidate teachers' opinions on teaching profession. Afyon Kocatepe University Social Sciences Journal, 9 (2), 221-232.

Papanastasiou, C. (2002). School, teaching and family influence on student attitudes toward science: Based on TIMSS data for Cyprus. Studies in Educational Evaluation, 28, 71-86. http://dx.doi.org/10.1016/S0191-491X(02)00013-5

Sarıgöz, O., \& Çermik,Y. (2013). Maslow's burnout measure vocational with students evulation of the levels of burnout determined. Journal of Research in Education and Teaching, 1(2), 116-122.

Semerci, N., \& Semerci, Ç. (2004). Teacher attitudes in Turkey. Firat UniversitySocial Sciences Journal, 14 (1), 137-146.

Tavşanc1l, E. (2006). Measurement of attitudes and data analysis with SPSS. Ankara: Nobel.

Temizkan M. (2008). A research onTurkish teachers' attitudes towards the teaching profession. Journal of Turkish Educational Sciences, 6(3), 461-486.

Terzi, A. R., \& Tezci, E. (2007). The attitudes of the students towards teaching profession at Necatibey education faculty. Educational Administration: Theory and Practice, 52, 593-614.

Üstüner, M. (2006). Öğretmenlik Mesleğine Yönelik Tutum Ölçeğinin Geçerlik ve Güvenirlik Çalışması, Educational Administration: Theory and Practice, 12 (45), 109-127.

Zhang, Y., Gan, Y., \& Cham, H. (2005). The reliability and validity of MBI-SS and academic characteristics affecting burnout. Chinese Journal of Clinical Psychology, 13, 383-385.

\section{$(\mathrm{cc}) \mathrm{EY}$}

This work is licensed under a Creative Commons Attribution 3.0 License. 